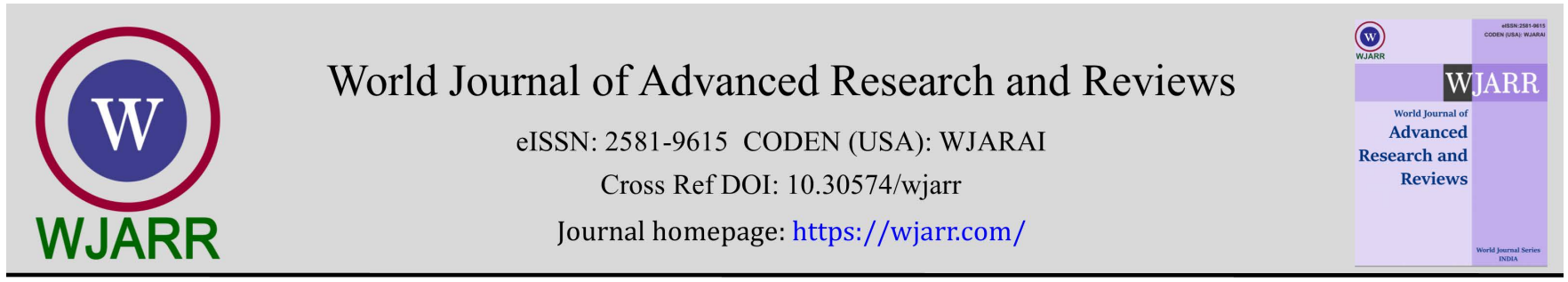

(RESEARCh ARTiCLE)

Check for updates

\title{
Seasonal variation in the physicochemical and bacteriological qualities of well water in two sub-divisions of Moundou city (Southern Chad, Central Africa)
}

\author{
Jaïrus Dionkas 1, 3, Antipas Ban-bo Bebanto 2, Naré Bongo Ngandolo ${ }^{3}$, Mian-Oudanang Kossou ${ }^{3}$ and Serge \\ Hubert Zébazé Togouet ${ }^{1, *}$ \\ 1 Laboratory of Hydrobiology and Environment, Faculty of Science, University of Yaoundé I, P.O. BOX 812, Yaoundé, \\ Cameroon. \\ ${ }^{2}$ Laboratory of Biochemistry, Cellular and Molecular Biology, Microbiology (L2BCM) University of N'Djamena, Chad. \\ ${ }^{3}$ Institute of Research in Animal Husbandry for Development (IRED) P.O. BOX 433, N'Djamena, Chad.
}

World Journal of Advanced Research and Reviews, 2021, 12(02), 332-345

Publication history: Received on 08 Jully 2021; revised on 06 November 2021; accepted on 08 November 2021

Article DOI: https://doi.org/10.30574/wjarr.2021.12.2.0321

\begin{abstract}
This study were carried out from May 2019 to July 2020 with the aimed of evaluating the physicochemical and bacteriological quality of well water in the City of Moundou (Chad). The physicochemical analysis showed that, the water from wells in the two sub-divisions were of very poor quality with an average concentration in Suspended Solids (SS) $30.73 \pm 21.72 \mathrm{mg} . \mathrm{L}^{-1}$, a Turbidity of $11.10 \pm 13.34 \mathrm{FTU}$, the Electrical Conductivity of $1625.9 \pm 1398.6$, a Total hardness of $1693.1 \pm 1198.2 \mathrm{mg} . \mathrm{L}^{-1}$, Biochemical Oxygen Demand (BOD 5 ) of $167.67 \pm 60,28 \mathrm{mg} . \mathrm{L}^{-1}$, the Chemical Oxygen Demand (COD) $605.93 \pm 259.98 \mathrm{mg} . \mathrm{L}^{-1}$ and organic matter $3.75 \pm 2.40 \mathrm{mg} . \mathrm{L}^{-1}$. The contamination rate (\% non-compliance) of the water points indicates that, during the rainy season the wells were moderately contaminated. Salmonella spp and Escherichia coli induced 29\% and 14\% respectively, of samples which did not comply with the WHO evaluation criteria (0 germ $/ \mathrm{mL})$. As for Total Coliforms and Fecal Coliforms, they were 93\% non-compliant each time in the well water samples analyzed. During the dry season, the wells were heavily contaminated with Salmonella spp, Escherichia coli, Total Coliforms and Fecal Coliforms induced approximately $100 \%$ of samples were not conform to the criteria of the WHO $(0$ germ $/ \mathrm{mL})$. These waters are therefore not safe for direct consumption without treatment.
\end{abstract}

Keywords: Water quality; Physico-chemistry; Bacteriology; Wells; Health risk; Moundou; Chad.

\section{Introduction}

Water is one of the most important natural resources, and certainly the most precious [1]. Every human regardless of their living conditions or resources, has the right to drink safe water. As a result, water has been placed at the center of all concerns and has been consecrated as a limited, vulnerable resource, essential to the environment, to development and essential to life [2].

In Chad, the problem of drinking water supply is acute and is one of the major concerns of the population, the State and its development partners. The Chadians Society of Water (STE), which supplies the country's main cities, is experiencing enormous difficulties in providing its services [3]. These difficulties are linked to population growth, the expansion of cities, the low production of drinking water, untimely power cuts and, above all, the obsolescence of the machines [3,4]. Limited access to water services (43\%) and sanitation (10\%) affects the health and nutrition situation in the country [4]. Insufficient drinking water leads the population to consume unsafe water with risks of waterborne diseases such as cholera, hepatitis, typhoid fever, skin diseases [5]. These have a direct impact on the survival of the population,

\footnotetext{
* Corresponding author: Zébazé Togouet Serge Hubert

Laboratoire d'Hydrobiologie et Environnement, Faculté des Sciences, Université de Yaoundé I, P.O. Box 812, Yaoundé, Cameroun.

Copyright (C) 2021 Author(s) retain the copyright of this article. This article is published under the terms of the Creative Commons Attribution Liscense 4.0.
} 
especially children, and on the socio-economic situation of households. According to the MICS Chad [4], each year 9,000 Chadian children die from diarrhea and almost one child in five suffers from it on a daily basis.

In the city of Moundou in southern Chad, water from traditional open wells remains a preferred source of drinking water due to its relative ease of use and the precarious economic situation of the population. However, the Chadian population in general and that of the city of Moundou in particular do not sufficiently take into account the obvious link between water quality, hygiene, sanitation and its importance for public health [6]. Numerous studies have been conducted on groundwater quality in the equatorial zone of Central Africa $[2,7,8,9]$. They show the impact of anthropic pressure that generate polluting elements that can affect the physicochemical and biological quality of water [10, 11, 12]. Very little data is available in Chad on the quality of the water in wells, which are of vital importance in the epidemiological study on the health of the population consuming these waters [8]. Indeed, these pollutions are not without risks for the riparian population $[13,14,15]$. This study aims to contribute to a better knowledge of the impact of anthropic pressure on the quality of well water used by the population of the city of Moundou and its risks on human health.

\section{Material and methods}

\subsection{Presentation of the study area}

The city of Moundou, capital of the Western Logone Province in southern Chad, is located between $08^{\circ} 32^{\prime} 20.1^{\prime \prime}$ and $08^{\circ} 33^{\prime} 11.8^{\prime \prime}$ North latitude and between $16^{\circ} 03^{\prime} 59.3^{\prime \prime}$ and $16^{\circ} 04^{\prime} 45.0^{\prime \prime}$ East longitude. In this city the rainfall varies between $1000 \mathrm{~mm}$ and more than $1200 \mathrm{~mm}$ with temperatures between $10^{\circ} \mathrm{C}$ and $45^{\circ} \mathrm{C}$. The flood zones cover about 1000 ha representing $47 \%$ of the total area of the city $\left(22 \mathrm{~km}^{2}\right.$ ) [16]. The city of Moundou shares its western border with the Republic of Cameroon and the Mayo-Kebbi West Region, it is bordered to the north by the Tandjilé West Region, to the east by the Tandjilé East and Central Regions and to the south by the Logone Oriental Province. The materials and methods should be typed in Cambria with font size 10 and justify alignment. Author can select Normal style setting from Styles of this template.

\subsubsection{Study period}

Sampling were conducted from May 2019 to July 2020; this period covers both seasons in Chad. A total of 56 water samples were collected from 14 wells. The samples were taken by campaign, one in the rainy season and two in the dry season.

\subsubsection{Selection and description of sampling stations}

The sampling stations were chosen according to accessibility, the interest of the populations for these water points, the location in relation to the surface sources of pollution, the morphological and hydrological state among others.

Table 1 Distribution of neighborhoods and stations in the two sub-divisions of the city of Moundou

\begin{tabular}{|c|l|l|c|}
\hline $\begin{array}{c}\text { sub- } \\
\text { divisions }\end{array}$ & \multicolumn{1}{|c|}{ Characteristics of the sub-divisions } & \multicolumn{1}{|c|}{$\begin{array}{c}\text { Number of } \\
\text { neighbourhoods } \mathbf{N}=\mathbf{8}\end{array}$} & $\begin{array}{c}\text { Number of wells } \\
\text { N=14 }\end{array}$ \\
\hline \multirow{3}{*}{} & $\begin{array}{l}\text { Presence of industrial units: } \\
\text {-Cotton fiber cotton ginning plant, } \\
\text {-The breweries of Chad (BDT), } \\
\text {-Chad cigarette factory (MCT), } \\
\text {-The Doyon sub-division is affected by the } \\
\text { problem of overflowing Lake Wey. }\end{array}$ & Doyon, Dokab & 6 \\
\hline II & $\begin{array}{l}\text { - Residential neighbourhoods } \\
\text {-Central Market }\end{array}$ & $\begin{array}{l}\text { Dombao, Maguirmi, Haoussa, Guelbé } \\
\text { Mbomian }\end{array}$ & 8 \\
\hline
\end{tabular}

At the end of the survey, 14 stations were selected in the two sub-divisions of the city of Moundou including six (6) in the first sub-division (I) and eight (8) in the second sub-division (II) (Table 1). These neighborhoods were chosen based 
on the precarious situation of households that use these well waters for their domestic needs [17]. The wells are coded P1 to P14 (Fig 1).

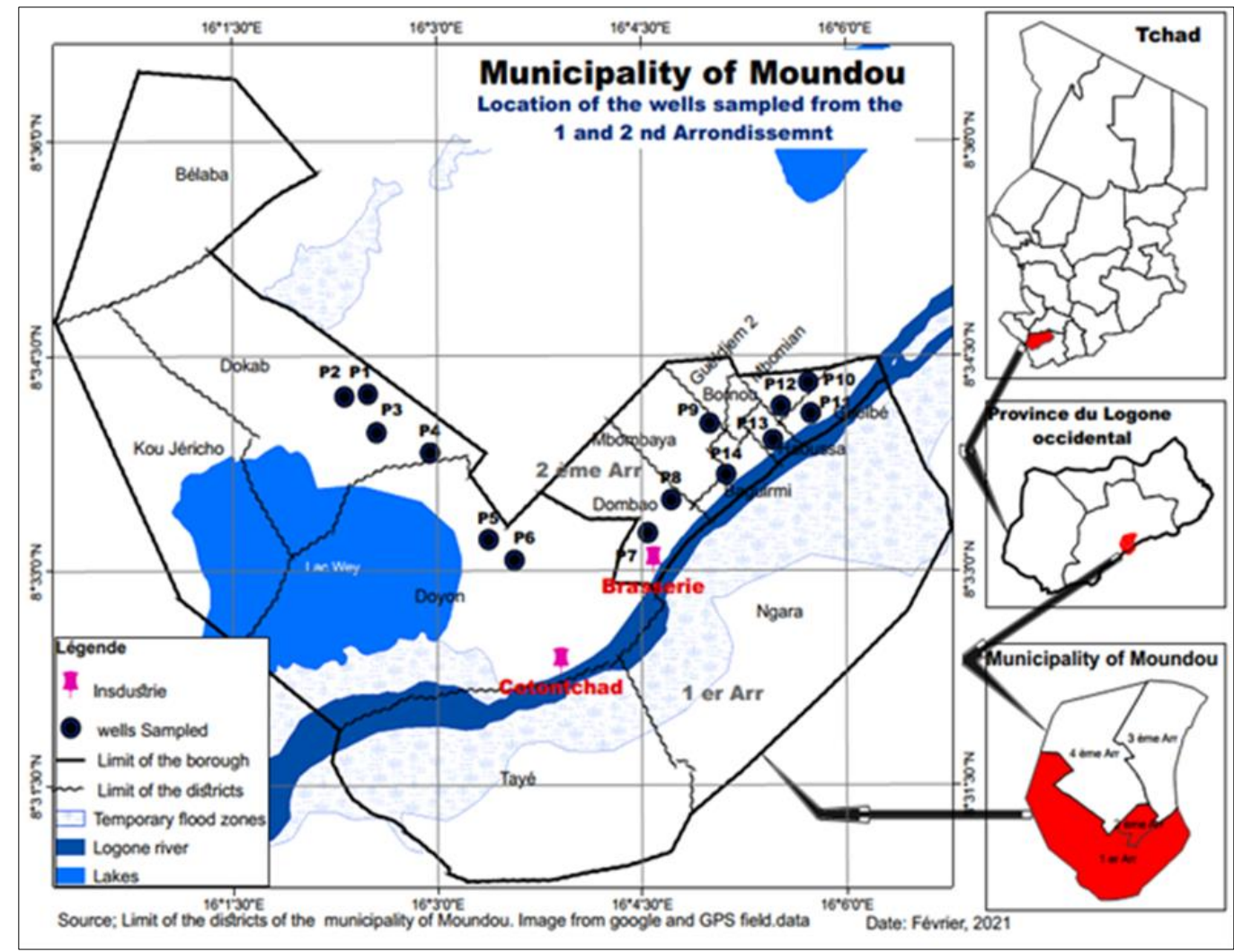

Figure 1 Location of sampling stations in the 1st and 2nd sub-divisions of the city of Moundou.

\subsection{Water sampling for various analysis}

\subsubsection{Microbiological analysis}

The water samples were carried out under aseptic conditions with a flame using a flashlight and sterile glass bottles of $250 \mathrm{ml}$ at the level of the curbstone at about $50 \mathrm{~cm}$ from the free surface. These samples were stored in a cooler with dry ice to maintain the temperature at $4^{\circ} \mathrm{C}$ and taken to the laboratory for analysis [18].

\subsubsection{Physicochemical analysis}

For physicochemical analysis, water were collected using a $5 \mathrm{~L}$ bucket attached to a rope and then transferred without bubbling into the $250 \mathrm{~mL}$ and $1000 \mathrm{~mL}$ double-capped polyethylene bottles and brought back to the laboratory in a refrigerated cabinet.

\subsubsection{Hydromorphometric parameters}

The morphometric parameters that allowed us to describe sample stations were the total depth of the well (Prof), the height of the curbstone (Hmarg), the type of curbstone (Tmarg), the diameter (Dtre), the opening (Ouv.) and closing (Ferm.) of the wells. The hydrological parameters measured were the thickness of the water column (EC) and the piezometric level (NP). The distance to the latrine (Dlat), the altitude (Alt).

\subsection{Sample Analysis}

\subsubsection{Physicochemical analyses}

To characterize the physicochemical quality of water, several parameters were measured according to the analysis methods recommended by Rodier and APHA $[18,19]$. 
Temperature, pH and dissolved oxygen were measured in the field using a HACH HQ40d multi-functional conductivity meter. Electrical Conductivity were also measured "in situ" using a HANNA (OAKTON) portable TDS / Conductivity meter. Total hardness were measured volumetrically in the laboratory using a HACH Digital Titrator Model 16900. Turbidity, Suspended Solids, Orthophosphates $\left(\mathrm{PO}_{4}^{3+}\right)$ and different forms of Nitrogen $\left(\mathrm{NH}_{4}^{+}\right.$, $\mathrm{NO}_{2}{ }^{-}$and $\left.\mathrm{NO}_{3}{ }^{-}\right) \mathrm{were}^{-}$ measured spectrophotometrically with a HACH DR/2400 spectrophotometer using Nitriver III, Nitraver V and Phosver III reagents respectively. Readings were taken at wavelengths $=500 \mathrm{~nm},=507 \mathrm{~nm}$ and $=530 \mathrm{~nm}$. The values of Biochemical demand in dioxygen consumed in 5 days (BOD 5 ) were obtained by respirometry from a BOD meter incubator, Model BOD trak II.

\subsubsection{Bacteriological analysis}

Pollution indicator germs searched for include Total Coliforms (TC), Faecal Coliforms (FC), Escherichia coli (EC) and Salmonella spp (Sal) bacteria. These bacterial species were chosen because of their importance in hygiene and public health in indicating the microbiological quality of drinking water $[18,20]$. The membrane filter method of enumeration of bacteria in water consisted of filtering $100 \mathrm{ml}$ of sample water through a $0.45 \mu \mathrm{m}$ pore size membrane [21]. All bacteria were retained on the surface of the membrane. This membrane were then placed in an solution of peptone water, followed by an incubation phase at laboratory temperature for $30 \mathrm{~min}$ to allow revival of the filtered bacteria. From this stock solution, a dilution were made to $10^{-1}$, then to $10^{-2}$ in solution of peptone water (ISO 657/A1). Each dilution were homogenized using an electric vortex mixer (Toporix FB 15024). The $10^{-2}$ dilution solution were used for the determination of the different bacterial germs. The enumeration of the isolated germs were done by direct counting on Petri dish and the bacterial abundances are expressed in number of colonies $\times 10^{+\mathrm{X}} \mathrm{CFU}$ (Colony Forming Unit $/ \mathrm{mL}$ of water) according to the following standards (Table 2):

Table 2 Isolation culture medium and incubation condition

\begin{tabular}{|l|l|l|l|}
\hline \multicolumn{1}{|c|}{$\begin{array}{c}\text { Bacteria } \\
\text { sought }\end{array}$} & \multicolumn{1}{|c|}{ Culture medium } & \multicolumn{1}{c|}{ Incubation + enumeration } & \multicolumn{1}{c|}{ Standards } \\
\hline Total Coliforms & VRBL & $37^{\circ} \mathrm{C}$ while $24 \mathrm{~h} \pm 2 \mathrm{~h}$ & ISO 4832 (February 2006) \\
\hline Fecal Coliforms & VRBL & $44^{\circ} \pm 1^{\circ} \mathrm{C}$ while $24 \mathrm{~h}$ & NF V 08-060 \\
\hline Salmonella spp. & $\begin{array}{l}\text { RVS (Ref: } 7730 \mathrm{~A}) \\
\text { XLD (Ref: } 51049) \\
\text { Kligler-hajna }\end{array}$ & $31050)$ & NF/EN ISO) 6579 (2002) \\
\hline Escherichia coli. & TBX & $47^{\circ} \mathrm{C}$ while $24 \mathrm{~h} \pm 3 \mathrm{~h}$ & \\
\hline
\end{tabular}

PCA: Plate Count Agar; VRBL: Violet Crystal Agar with Neutral Red Bile and Lactose; HKT: Hektoën; RVS: Rappaport Vassiliadis Soja; XLD: Deoxycholate; TBX: Triptone Bile X

\subsection{Statistical analysis}

Data processing were performed using Microsoft-Excel 2016 spreadsheet software. Analyses of variances, comparison of means and study of spatial and spatiotemporal variability from one site to another were performed using the KruskalWallis test associated with Mann-Whitney. Spearman correlations between morphohydrological, physicochemical and bacteriological variables measured were analyzed using SPSS version 16.0 software. Histograms were plotted using GraphPad Prism version 8.0.

\section{Results and discussion}

\subsection{Hydromorphometric characterization}

Four selected wells used concrete covering (P1, P2, P3 and P4); one had concrete and wheel coping (P6); and one well (P5) had wheel coping (Table 3). Of the eight wells sampled in the second sub-division, the wells that were consistently open were (P7, P8, P9) and (P12, P13, P14). Except, wells P11 and P12 are closed. These wells have the lowest water volumes compared to the other stations in the 1st sub-division (Table 3).

Overall, the construction profile of the sampled wells on the urban plan is different from one well to another and from one locality to another. Thus, there are (08) wells with concrete coping, (03) wells with concrete coping + wheel and 
(03) wells with wooden wheel coping (0). The height of these different covering varied from 0.4 to $0.78 \mathrm{~m}$. The highest covering were those made of concrete $(0.78 \mathrm{~m})$. Of the fourteen wells, eleven (11) were constantly open, i.e. 78.57\% and the remaining three (03) were closed, i.e. $21.43 \%$. The depth of the wells varied between 3.15 and $20.79 \mathrm{~m}$. The largest diameter of the wells were $1.70 \mathrm{~m}$.

Table 3 Morphometric and hydrological characteristics of the different stations studied

\begin{tabular}{|c|c|c|c|c|c|c|c|c|c|c|c|}
\hline $\begin{array}{l}\text { Sub- } \\
\text { divisions }\end{array}$ & $\begin{array}{l}\text { Neigh } \\
\text { borhoods }\end{array}$ & $\begin{array}{l}\text { Station } \\
\text { s }\end{array}$ & $\begin{array}{l}\text { Open } \\
\text { closed }\end{array}$ & $\begin{array}{l}\text { Tmarg } \\
(\mathrm{m})\end{array}$ & $\begin{array}{l}\text { Alt } \\
(\mathrm{m})\end{array}$ & $\begin{array}{l}\text { NP } \\
(\mathrm{m})\end{array}$ & $\begin{array}{l}\text { CE } \\
(\mathrm{m})\end{array}$ & $\begin{array}{l}\text { Prof } \\
\text { (m) }\end{array}$ & $\begin{array}{l}\text { Dtre } \\
(\mathrm{m})\end{array}$ & $\begin{array}{l}\text { Hmarg } \\
(\mathrm{m})\end{array}$ & $\begin{array}{l}\text { Dlat } \\
\text { (m) }\end{array}$ \\
\hline \multirow{6}{*}{$\begin{array}{l}1 \text { st } \\
\text { Sub- } \\
\text { division } \\
\text { (I) }\end{array}$} & \multirow{4}{*}{ Dokab } & P1 & open & concrete & 401 & 4.65 & 6.8 & 11 & 0.7 & 0.48 & 19.8 \\
\hline & & P2 & closed & concrete & 405 & 3.11 & 5.24 & 8.4 & 0.1 & 0.6 & 16.6 \\
\hline & & P3 & open & concrete & 396 & 4.55 & 6.3 & 11 & 0.9 & 0.53 & 14.6 \\
\hline & & P4 & open & concrete & 405 & 1.5 & 5.8 & 7.3 & 1.7 & 0.45 & 17.5 \\
\hline & \multirow[b]{2}{*}{ Doyon } & P5 & open & wheel coping & 403 & 2.69 & 5 & 7.7 & 0.1 & 0.4 & 16.6 \\
\hline & & P6 & open & $\begin{array}{l}\text { concrete }+ \\
\text { wheel coping }\end{array}$ & 400 & 6.5 & 14.3 & 21 & 1.2 & 0.68 & 16.1 \\
\hline \multirow{8}{*}{$\begin{array}{l}2 \text { nd } \\
\text { Sub- } \\
\text { division } \\
\text { (II) }\end{array}$} & \multirow{2}{*}{ Dombao } & P7 & open & concrete & 412 & 0.7 & 2.45 & 3.2 & 0.1 & 0.5 & 11 \\
\hline & & P8 & open & concrete & 394 & 0.52 & 4.82 & 5.3 & 0.8 & 0.6 & 14.8 \\
\hline & Mbombaya & P9 & open & concrete & 399 & 6.64 & 2.25 & 8.9 & 1.3 & 0.57 & 6.35 \\
\hline & Mbomian & P10 & closed & concrete & 395 & 2.99 & 6.6 & 9.6 & 1.2 & 0.5 & 15.1 \\
\hline & Guelbé & P11 & closed & \begin{tabular}{|l|} 
concrete + \\
wheel coping
\end{tabular} & 394 & 2.04 & 3.58 & 5.6 & 1.3 & 0.64 & 22.4 \\
\hline & Mbomian & P12 & open & $\begin{array}{l}\text { concrete }+ \\
\text { wheel coping }\end{array}$ & 392 & 3.03 & 3.34 & 6.4 & 1.1 & 0.6 & 17.5 \\
\hline & Haoussa & P13 & open & wheel coping & 395 & 4.1 & 3.13 & 7.2 & 0.9 & 0.47 & 9.4 \\
\hline & Baguirmi & P14 & open & wheel coping & 396 & 3.57 & 4.3 & 7.9 & 1.6 & 0.48 & 14.4 \\
\hline \multirow{4}{*}{\multicolumn{4}{|c|}{$\begin{array}{l}\text { Mean values } \pm \text { standard } \\
\text { hydromorphometric }\end{array}$}} & $\begin{array}{l}\text { WHO } \\
\text { Standards }\end{array}$ & - & - & - & - & - & $1-1.5$ & 15 \\
\hline & & & & Minimum & 392 & 0.52 & 2.25 & 3.15 & 0.1 & 0.4 & 6.35 \\
\hline & & & & Maximum & 412 & 6.64 & 14.29 & 20.79 & 1.7 & 0.68 & 22.43 \\
\hline & & & & Mean \pm St.D & $\begin{array}{l}399 \pm \\
5.62\end{array}$ & $\begin{array}{l}3.32 \pm \\
1.86\end{array}$ & $\begin{array}{l}5.2 \pm \\
2.99\end{array}$ & $\begin{array}{l}8.6 \pm \\
4.13\end{array}$ & $\begin{array}{l}0.9 \pm \\
0.52\end{array}$ & $\begin{array}{l}0.53 \pm \\
0.08\end{array}$ & $\begin{array}{l}15.1 \pm \\
4.10\end{array}$ \\
\hline
\end{tabular}

Alt: the altitude; NP: the piezometric level; EC: the thickness of the water column; Prof: the depth of the well; Dtre: the diameter; Tmarg: the type of curbstone; Hmarg: the height of the curbstone; Dlat: the distance to the latrine.

The results of this study show that the highest coverings were those made of concrete $(0.78 \mathrm{~m})$ among which eleven (11) or $78.57 \%$ of the wells were constantly open and three $(03)$ or $21.43 \%$ remaining were closed. According to Maoudombaye [13], these structures often poorly protected, strongly accentuate the degree of contamination of these waters. Our results confirm this information.

\subsection{Physicochemical characterization}

The temperatures recorded in the study stations were very similar with the average value of $29.04^{\circ} \mathrm{C} \pm 1.09^{\circ} \mathrm{C}$ (Table 4 ). 
Table 4 Average values \pm standard deviations of physicochemical parameters of the stations sampled in the two sub-divisions of the city of Moundou

\begin{tabular}{|c|c|c|c|c|c|c|c|c|c|c|c|}
\hline Sub & Stations & $\mathbf{T}^{\circ}$ & pH & MES & Turb & C.E & TH & $\mathrm{O}_{2}$ sat & $\mathrm{DBO}_{5}$ & DCO & MO \\
\hline \multirow{6}{*}{ I } & $\mathrm{P} 1$ & $28.7 \pm 0.11$ & $6.86 \pm 0.69$ & $23.2 \pm 12.37$ & $34.9 \pm 19.65$ & $351.7 \pm 63.28$ & $434 \pm 15.55$ & $0.697 \pm 0.47$ & $199.3 \pm 111.89$ & $292.25 \pm 184.2$ & $1.75 \pm 2.47$ \\
\hline & $\mathrm{P} 2$ & $28.6 \pm 0.20$ & $6.81 \pm 0.85$ & $17.5 \pm 6.36$ & $25.6 \pm 31.6$ & $415.2 \pm 175.00$ & $288 \pm 2.82$ & $0.68 \pm 0.35$ & $208.8 \pm 44.75$ & $509.75 \pm 163.6$ & $2 \pm 1.41$ \\
\hline & P3 & $28.2 \pm 0.40$ & $6.80 \pm 1.07$ & $56.2 \pm 25.80$ & $18.5 \pm 2.89$ & $285 \pm 56.56$ & $369 \pm 48.08$ & $0.612 \pm 0.59$ & $178.2 \pm 70.12$ & $438.5 \pm 174.65$ & $2.5 \pm 2.12$ \\
\hline & $\mathrm{P} 4$ & $28.9 \pm 0.11$ & $6.78 \pm 0.88$ & $29.2 \pm 20.15$ & $4.09 \pm 1.54$ & $413.9 \pm 94.82$ & $359 \pm 100.40$ & $1.53 \pm 1.25$ & $181.4 \pm 47.74$ & $559 \pm 171.11$ & $2.75 \pm 0.35$ \\
\hline & P5 & $28.9 \pm 0.46$ & $6.42 \pm 0.52$ & $53.7 \pm 6.71$ & $5.83 \pm 1.64$ & $935.7 \pm 76.72$ & $944.2 \pm 119.85$ & $0.815 \pm 0.36$ & $194.1 \pm 89.51$ & $1086.2 \pm 544$ & $4.75 \pm 0.35$ \\
\hline & P6 & $29.1 \pm 0.2$ & $6.58 \pm 0.80$ & $47 \pm 33.94$ & $2.48 \pm 2.14$ & $2519 \pm 481.53$ & $2071 \pm 178.54$ & $1.03 \pm 0.24$ & $217.3 \pm 62.66$ & $670.25 \pm 56.21$ & $2.5 \pm 0.70$ \\
\hline \multirow{8}{*}{ II } & P7 & $28.5 \pm 0.03$ & $6.79 \pm 0.63$ & $33.5 \pm 2.12$ & $12.0 \pm 7.05$ & $685.7 \pm 623.31$ & $1207 \pm 293.80$ & $0.74 \pm 0.50$ & $202.5 \pm 77.58$ & $717.25 \pm 96.52$ & $3.25 \pm 1.70$ \\
\hline & P8 & $29.2 \pm 0.49$ & $6.93 \pm 0.63$ & $18.5 \pm 20.50$ & $3.85 \pm 4.44$ & $2311 \pm 365.57$ & $1840 \pm 416.48$ & $0.642 \pm 0.47$ & $196.2 \pm 50.72$ & $519.75 \pm 56.21$ & $2.5 \pm 0.70$ \\
\hline & P9 & $29.1 \pm 0.03$ & $6.91 \pm 0.64$ & $12.5 \pm 12.02$ & $3.35 \pm 3.74$ & $1867 \pm 9.89$ & $1912 \pm 305.11$ & $1.45 \pm 1.07$ & $132.9 \pm 8.94$ & $658.75 \pm 54.09$ & $5.25 \pm 0.35$ \\
\hline & $\mathrm{P} 10$ & $29.6 \pm 0.49$ & $6.58 \pm 0.28$ & $27 \pm 11.31$ & $17.9 \pm 24.1$ & $3428 \pm 906.8$ & $3065 \pm 1236.7$ & $1.24 \pm 0.67$ & $130.8 \pm 41.77$ & $436.5 \pm 33.23$ & $3 \pm 1.41$ \\
\hline & $\mathrm{P} 11$ & $28.9 \pm 1.37$ & $6.60 \pm 0.37$ & $24 \pm 19.79$ & $4.41 \pm 3.65$ & $3589 \pm 3182.6$ & $3708 \pm 1379.2$ & $0.67 \pm 0.41$ & $124.4 \pm 38.79$ & $777.25 \pm 121.2$ & $5.75 \pm 1.06$ \\
\hline & $\mathrm{P} 12$ & $29.4 \pm 0.95$ & $6.66 \pm 0.42$ & $59.2 \pm 20.15$ & $11.4 \pm 13.5$ & $851.7 \pm 723.72$ & $3162 \pm 687.30$ & $1.67 \pm 1.38$ & $89.67 \pm 1.49$ & $536 \pm 379$ & $5.75 \pm 4.59$ \\
\hline & P13 & $29.1 \pm 0.81$ & $6.91 \pm 0.53$ & $25.5 \pm 33.23$ & $5.84 \pm 3.05$ & $3474 \pm 404.46$ & $2510 \pm 606.69$ & $0.78 \pm 0.36$ & $139.2 \pm 77.58$ & $812 \pm 5.65$ & $6.75 \pm 3.88$ \\
\hline & P14 & $29.4 \pm 1.30$ & $7.08 \pm 0.28$ & $3 \pm 1.141$ & $5.17 \pm 5.41$ & $1633 \pm 213.89$ & $1831 \pm 544.11$ & $0.57 \pm 0.55$ & $151.9 \pm 83.55$ & $469.5 \pm 437.69$ & $4 \pm 5.65$ \\
\hline \multirow{4}{*}{$\begin{array}{c}\text { Physico- } \\
\text { Chemical } \\
\text { parameters } \\
\text { variation }\end{array}$} & $\begin{array}{c}\text { WHO } \\
\text { Std. (2011) }\end{array}$ & $<25$ & $6.5-8.5$ & $<15$ & $<5$ & 250 & $10-15$ & $60 \%$ & 5 & 25 & 0 \\
\hline & Min & 27.9 & 5.87 & 2 & 0.7 & 245 & 286 & 0.18 & 84.4 & 160 & 0 \\
\hline & Max & 30.35 & 7.74 & 74.5 & 48.8 & 5840 & 4684 & 2.66 & 278.52 & 1471 & 9.5 \\
\hline & Mean \pm St.D & $29.0 \pm 0.61$ & $6.76 \pm 0.60$ & $30.7 \pm 21.72$ & $11.1 \pm 13.34$ & $1625 . \pm 1398$ & $1693 . \pm 1198$ & $0.94 \pm 0.63$ & $167.6 \pm 60.28$ & $605.93 \pm 259.98$ & $3.75 \pm 2.40$ \\
\hline
\end{tabular}

T: Temperature $\left({ }^{\circ} \mathrm{C}\right.$ ): $\mathrm{pH}$ : Potential dihydrogen (CU); MES: Suspended solids (mg/L), Turb: Turbidity (FTU); C E: Electrical conductivity ( $\mu \mathrm{S} / \mathrm{Cm}$ ): TH. Total hardness (mg/L CaCO4); $\mathrm{O}_{2}$ sat: 0 xygen saturation (\%); $\mathrm{CDO}\left(\mathrm{mg} / \mathrm{L} \mathrm{O}_{2}\right.$ ): Chemical Demand in Oxygen); $\mathrm{BDO}_{5}\left(\mathrm{mg} / \mathrm{L} \mathrm{O}_{2}\right)$ : Biochemical Demand in Oxygen during five days; $\mathrm{MO}$ (mg/L): Organic matter 
The average temperatures obtained (Table 4) were higher than the international standards for groundwater, which provide a maximum value of $25^{\circ} \mathrm{C}$ [18]. The average $\mathrm{pH}$ value over the entire two sampling periods is $6.76 \pm 0.60$. This indicates that the waters are acidic (Table 4). Well P14 presented a neutral pH with an average of 7.08 \pm 0.28 (Table 4). The $\mathrm{pH}$ averages of the samples collected were within the WHO recommended values $(6.5<\mathrm{pH}<8.5)(\mathrm{Table} 4)$. The analyzed waters have generally shown very high average values of suspended matter and conductivity, reflecting their strong mineralization. The waters were turbid with a high total hardness (Table 4). This justified the influence that anthropic activities and demography can have on the pollution of well water in urban areas. The presence of organic matter in the water indicates a real pollution factor. The waters here were highly polluted because the average organic matter concentration of the waters $3.75 \pm 2.40 \mathrm{mg} / \mathrm{L}$ is well above (Table 4$)$ the standard $\left(0 \mathrm{mg} \mathrm{O}_{2} / \mathrm{L}\right)$ recommended by the WHO.

The waters have shown a total hardness of 286.00 and $4684.00 \mathrm{mg} / \mathrm{L}$ with the average value of $1693.10 \pm 1198.2 \mathrm{mg} / \mathrm{L}$. Referring to the normal recommended rate (10 and $15 \mathrm{mg} / \mathrm{L})$, the well water is very hard. The increase in TH levels could be explained by exchanges during and after rainfall. These waters also present a risk of corrosion for the conservation stencils [18].

Dissolved oxygen levels were ranged between 18 and $26.6 \% \mathrm{O}_{2}$ with an average of $24 \pm 0.63 \% \mathrm{O}_{2}$. The decrease in oxygen content is significant. Several phenomena can explain this decrease: among which is the increase in temperature during the day, the water runoff that generates a continuous mixing of wastewater with well water and consequently enrichment in organic matter. The values of this parameter were close to the standards of potability while remaining lower. According to Belghiti [29], the low values of dissolved oxygenate favor the development of pathogens.

The analysis of organic parameters shows that COD varied from 160 to $1471 \mathrm{mg} / \mathrm{L}$ with an average of $605.93 \pm 292.98$ $\mathrm{mg} / \mathrm{L}$ and BOD 5 oscillated between 84.40 to $278.52 \mathrm{mg} / \mathrm{L}$ with an average of $167.67 \pm 60.28 \mathrm{mg} / \mathrm{L}$. The COD/BOD 5 ratios vary from 00 to 9.50 with an average of $3.75 \pm 2.40 \mathrm{mg} / \mathrm{L}$. It is noted that the majority of the wells have ratios strictly superior to 0 . According to the $\mathrm{WHO}$, the $\mathrm{COD} / \mathrm{BOD}_{5}$ ratio must be zero. This organic pollution can be linked to the leachate from public dumps which is the main vector of transport of metallic pollution from waste storage sites to the water table $[32,33]$.

\subsection{Bacteriological characterization of the studied stations}

Table 5 Assessment of the quality of well water tested in the city of Moundou during the study

\begin{tabular}{|c|c|c|c|c|}
\hline \multirow[t]{2}{*}{$\begin{array}{l}\text { Searched } \\
\text { germs }\end{array}$} & \multirow{2}{*}{$\begin{array}{c}\text { Extreme values } \\
\text { in CFU/ml } \\
\text { Intervals }\end{array}$} & \multirow{2}{*}{$\begin{array}{l}\text { Microbiological criteria } \\
\text { CFU/ml } \\
\text { (WHO standards, 2011) }\end{array}$} & \multicolumn{2}{|c|}{$\begin{array}{l}\text { Number of wells with } \\
\text { satisfactory values }\end{array}$} \\
\hline & & & Wells $\mathrm{N}=14$ & $\%$ \\
\hline \multicolumn{5}{|l|}{ Rainy season } \\
\hline Total Coliforms & $0-68$ & 0 & P8 (1) & 7 \\
\hline Fecal Coliforms & $0-32$ & 0 & P8 (1) & 7 \\
\hline Escherichia coli & $0-5$ & 0 & 10 & 71.5 \\
\hline Salmonella Spp & $0-58$ & 0 & 12 & 86 \\
\hline \multicolumn{5}{|l|}{ Dry season } \\
\hline Total Coliforms & $14-469$ & 0 & 0 & 0 \\
\hline Fecal Coliforms & $3-333$ & 0 & 0 & 0 \\
\hline Escherichia coli & $0-36$ & 0 & 4 & 28.5 \\
\hline Salmonella Spp & $2-45$ & 0 & 0 & 0 \\
\hline
\end{tabular}

Table 5 provides information on wells with satisfactory values according to standards of WHO [22]. The results have shown that only one well (P8) out of the 14 wells sampled showed satisfactory values for TC and CF respectively against the WHO standard (Table 5). While more than half, 10 to 12 of the 14 wells sampled showed satisfactory values of $71 \%$ and $85 \%$ respectively for Escherichia coli and Salmonella spp. On the other hand, in the dry season, the results of the 
microbiological analyses showed that very few of the wells showed satisfactory values for most of the pollution germs investigated, that is $0 \%, 0 \%, 28.5 \%$ and $0 \%$ respectively for CT, CF, Escherichia coli and Salmonella spp. Table V shows that the presumptive coliform test were positive in $100 \%$ of the wells sampled in the two sub-divisions of Moundou.

This operation made it possible to evaluate the contamination rate (\% of non-compliance) of the water points, as shown in Figure 2 below, which indicates that in the rainy season the wells were moderately contaminated. Salmonella spp, Escherichia coli induced respectively 29\%, 14\% of samples not conforming to the WHO evaluation criteria (0 germ/mL). TC and FC were found to be non-compliant in 93\% of the well water samples analyzed respectively (Figure 2). During the dry season, wells were highly contaminated. Total Coliforms, Fecal Coliforms, and Salmonella spp. all induced $100 \%$ non-compliant samples (0 germ /mL) except Escherichia coli which induced 71.5\% (Figure 2).

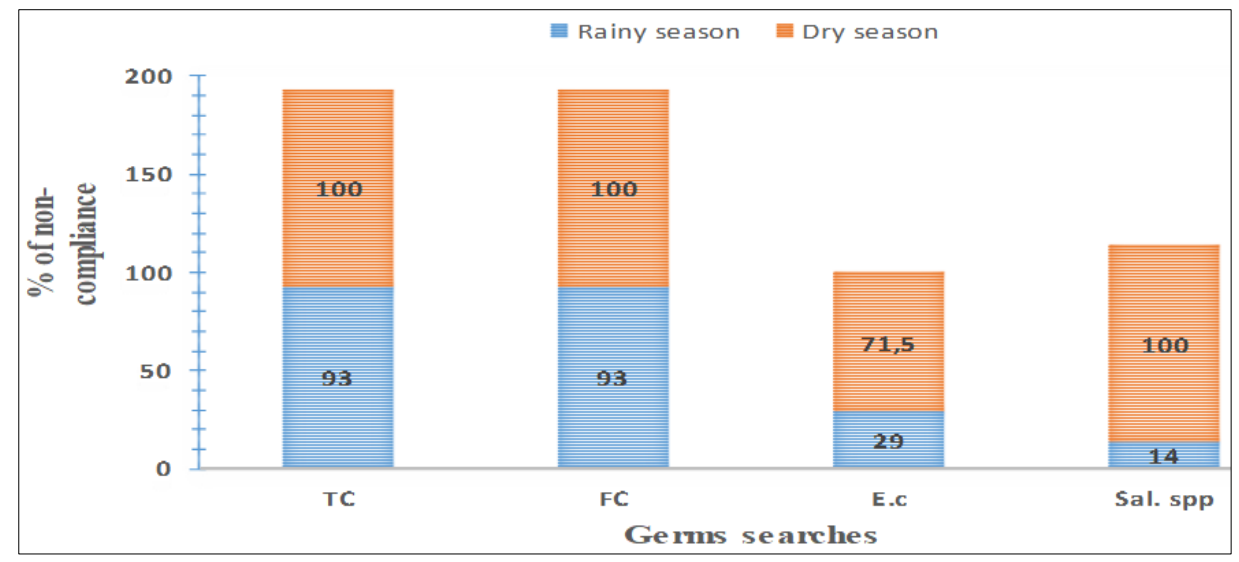

Figure 2 Non-compliance induced in relation to the germs tested. TC: Total Coliforms; FC: Fecal Coliforms; EC: Escherichia coli and Sal. spp: Salmonella spp

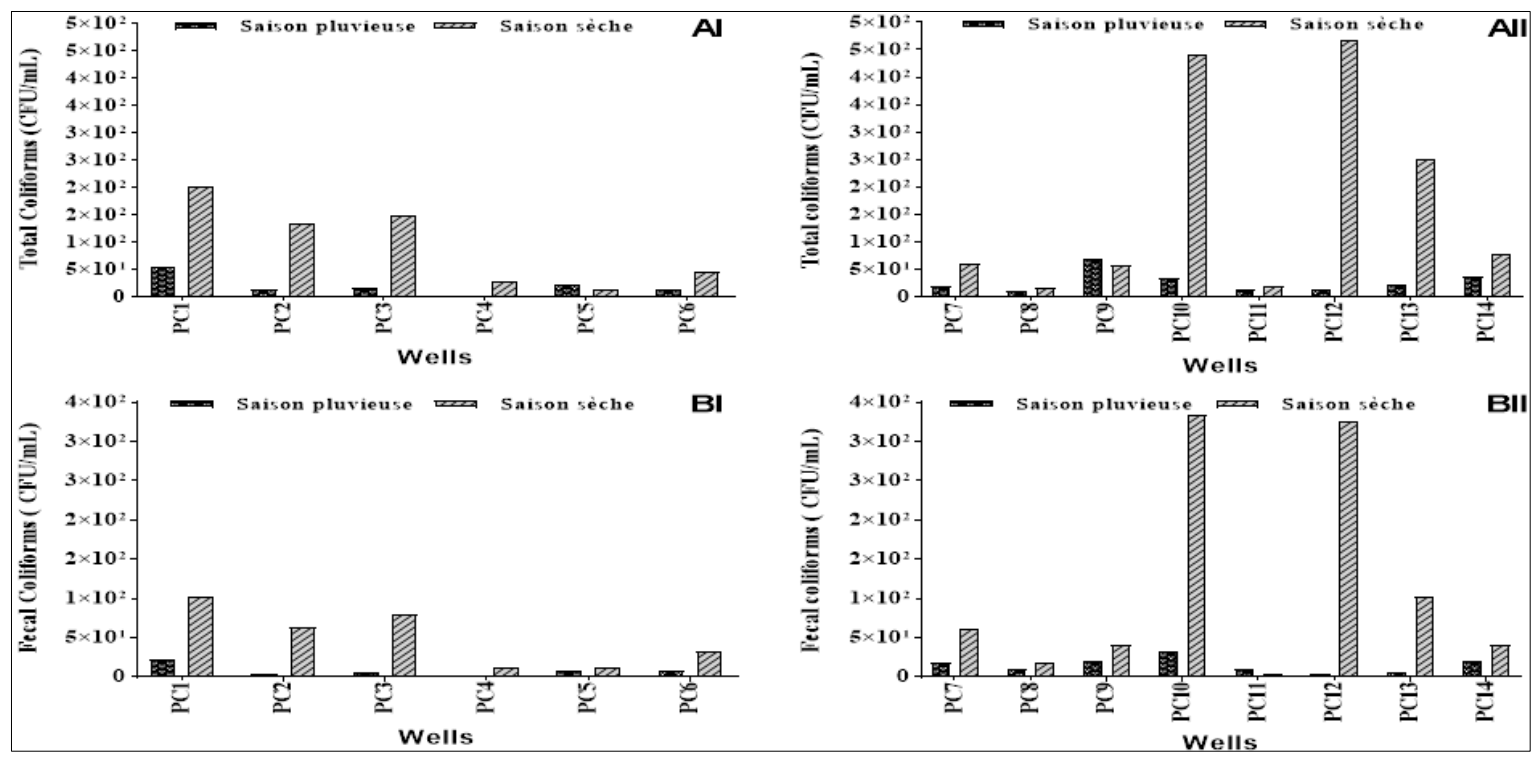

Figure 3 Seasonal variation in bacteriological abundance in well water in the city of Moundou during the study $(\mathrm{A}=$ TC); (B= FC). I: $1^{\text {st }}$ sub-division; II: $2^{\text {nd }}$ sub-division

Total Coliforms were a heterogeneous group of bacteria of fecal and environmental origin. In the wet season, and according to the (Figure 3AI and AII) below, the sampled well waters showed an average presence of $20.16 \pm 19.05$ $\mathrm{CFU} / \mathrm{ml}$ of Total Coliforms in the first sub-division (Figure 3AI) and an average of $26.75 \pm 19.27 \mathrm{CFU} / \mathrm{ml}$ in the second sub-division (Figure 3AII). While in the dry season, the TC presented an average of $20.16 \pm 19.05 \mathrm{CFU} / \mathrm{ml}$ in the first sub-division (Figure $3 \mathrm{AI}$ ) and an average of $95.16 \pm 77.08 \mathrm{CFU} / \mathrm{ml}$ in the second sub-division (Figure 3AII). This shows that Total Coliforms are less present in AI compared to AII. In the (Figure 3BI and 3BII), the average number of Fecal Coliforms is $7.33 \pm 7.28 \mathrm{CFU} / \mathrm{ml}$ in the well water sampled in the first sub-division (Figure $3 \mathrm{BI}$ ). In contrast, the mean 
value in the second sub-division (Figure 3BII) was $14.37 \pm 8.99 \mathrm{CFU} / \mathrm{ml}$ in the rainy season. While in the dry season, Fecal Coliforms gaved a mean value of $50.00 \pm 37.21 \mathrm{CFU} / \mathrm{ml}$ in the first arrondissement (Figure 3BI) and a significant presence in well water with values ranging from 3 to $333 \mathrm{CFU} / \mathrm{ml}$ and a mean of $112.88 \pm 136.52 \mathrm{CFU} / \mathrm{ml}$ in the second arrondissement (Figure 3BII).

In the rainy season, the bacterial density of Escherichia coli varied between 0 and $5 \mathrm{CFU} / \mathrm{ml}$ with an average of $1.00 \pm$ $2.00 \mathrm{CFU} / \mathrm{ml}$ in the first sub-division (Figure 4CI). This value remains constant in the second sub-division (Figure 4CII). It varied between 0 and $9 \mathrm{CFU} / \mathrm{ml}$ with an average of $3.16 \pm 5.53 \mathrm{CFU} / \mathrm{ml}$ in the first arrondissement (Figure 4CI) and with an average of $21.00 \pm 13.34 \mathrm{CFU} / \mathrm{ml}$ in the second arrondissement (Figure 4CII) in the dry season. In the rainy season, the number of Salmonella spp. is zero in the first arrondissement (Figure 4DI), but fluctuates between 0 and 58 $\mathrm{CFU} / \mathrm{ml}$ with an average of $9.12 \pm 20.43 \mathrm{CFU} / \mathrm{ml}$ in the second arrondissement (Figure 4DII). In the dry season, this number shows a mean result of $24.33 \pm 15.69 \mathrm{CFU} / \mathrm{ml}$ in the first sub-division (Figure 4DI) and a mean of $16.00 \pm 12.32$ $\mathrm{CFU} / \mathrm{ml}$ in the second sub-division (Figure 4DII). The maximum values of TC, CF, EC and Sal were obtained in the dry season in May and November in wells P1, P2, P3, P5 and P6 (Fig. 3 AI BI; figure 4DI), and wells P7, P9, P10, P12 and P13 (Figure 3AII, 3BII; figure 4CII and 4DII). In contrast, the results of the well water analyses revealed a decrease in the concentration of bacterial load in the majority of wells in the two sub-divisions of the city of Moundou.

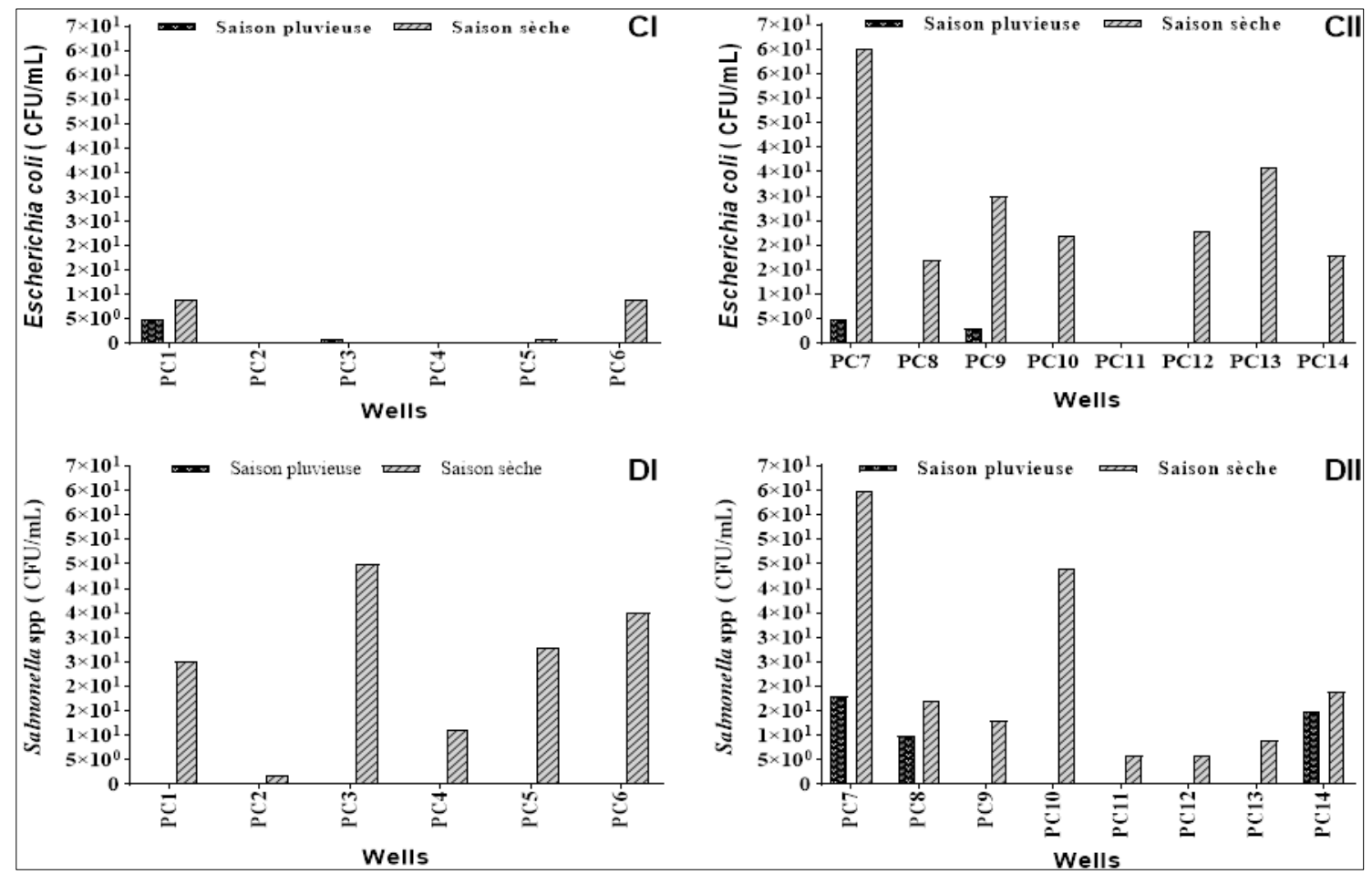

Figure 4 Seasonal variation in bacteriological abundance in well water in the city of Moundou during the study (C= EC); (D= Sal). I: $1^{\text {st }}$ sub-division; II: $2^{\text {nd }}$ sub-division

The analysis of water samples showed that the density of Total Coliforms (TC) ranged from 0 to $8.84 \times 102 \mathrm{CFU} / \mathrm{mL}$ with an average of $101.24 \pm 205.02 \mathrm{TC}$ in $1 \mathrm{ml}$ of sample. Referring to the WHO standard (0 TC in $100 \mathrm{ml}$ of sample), it is found that all analyzed waters exceed the required reference standard (Figure 3AI and 3AII). The number of TC is very high during the dry season. This high number can be justified by the drop in piezometric level during the dry season (May and November), compared to the one in August, which results in the concentration of germs at the lower level of the wells. Similarly, the influence of the high temperature $29.04 \pm 1.09$ contributes to explain this situation [34].

By comparing the number of CF germs obtained in the analyzed waters and the WHO and Union standard (0 coliforms in $100 \mathrm{ml}$ of sample), we deduce a microbiological pollution for the well waters. The number of CF varied from 0 to $6.56 \times 102 \mathrm{CFU} / \mathrm{mL}$ of sample. CF were indicators of treatment efficiency (disinfection) but do not necessarily indicate fecal pollution. However, the presence of Fecal Coliforms in all well water in the city of Moundou indicates that the water is unfit for human consumption. The WHO standards [22] do not tolerate any CFU/100ml of water. Our results corroborate with those carried out by $[7,23,35,36]$, respectively in Yaoundé, Douala Yaoundé, Ngaoundéré in 
Cameroon who revealed the fecal contamination by the individual or associated presence of Total Coliforms, Thermotolerant Coliforms, Fecal Enterococci in the well waters.

The number of Escherichia coli varied during the study from 0 and $0.71 \times 102 \mathrm{CFU} / \mathrm{mL}$ of sample (Figure 4CI and 4CII) with an average of $8.21 \pm 18.24 \mathrm{EC}$ in $1 \mathrm{ml}$ of sample. The wells have high concentrations of EC. The presence of EC in these waters indicates recent contamination of the wells, the sources of which would be the same as the CF. Our results confirm the recent study on the bacteriological quality of well water consumed in the Doba oil basin of Chad in Doba that reported the more notorious E. coli contamination of well water [13, 37].

The bacterial load concentration of Salmonella spp fluctuated from 0 to $0.76 \times 102 \mathrm{CFU} / \mathrm{ml}$ of sample. The results show an increase in Salmonella spp in the rainy season in PC8 (Figure 4DI). Studies by Dionkas, Benodji and Nang-yana [31, 38, 39] also showed that the bacteriological and/or chemical quality of groundwater deteriorated more in the rainy season. During the winter or rainy period, the increase in piezometric level accelerates the spread of pollutants that are on the ground or trapped in the unsaturated zone [40]. Seepage water favors pollution from septic tanks, leaky latrines [17] that interconnect with the wells $[17,41]$. This phenomenon would be explained by groundwater recharge, runoff during and after rainfall, or direct exposure of wells to wastewater and septic tank discharges or the poor state of protection of wells, in the majority of cases open $[42,43]$. Poorly constructed and maintained wells are highly exposed to the risk of contamination [44]. In this regard, [28], have shown that the abundance of these germs in well water could be due to local point source pollution at the surface, at or near the water points.

With regard to our microbiological results, we note that the water studied harbors numerous pathogenic bacteria, Total Coliforms (TC), Fecal Coliforms (FC), Escherichia coli (EC) and Salmonella spp (Sal). The results show an increase in the bacterial load in the dry season and a regression of the number of bacteria in the rainy season. Our results are similar to those of $[44,45]$ who estimated an increase in contamination rate during the dry season compared to the rainy period. Also, for $[46,47]$, rainy conditions may have a dilution role in the water table and therefore decrease the bacterial concentration in the water during the rainy season. The rise in temperature and evaporative processes during the dry season may also account for this increase [44]. The difference between the increase in contamination in the dry season and the decrease in the rainy season, depending on the germs tested for, is due to the fact that some households reported treating water before consumption, especially in the rainy season. This could also be explained by the height of the curbstone, which does not comply with the WHO standard of $1 \mathrm{~m}$. In addition to these sources, sewage treatment plant effluents, food processing plant effluents, and rainwater have also been reported [48]. Contamination of well water has been attributed to poor management of solid and liquid wastes from human activities $[14,49]$.

\subsection{Spearman correlation between the studied parameters}

Table 6 Spearman correlation coefficients between morphohydrological, physicochemical and bacteriological variables

\begin{tabular}{|c|c|c|c|c|}
\hline Variables & $\begin{array}{c}\text { Total } \\
\text { coliforms } \\
\end{array}$ & $\begin{array}{c}\text { Fecal } \\
\text { coliforms } \\
\end{array}$ & $\begin{array}{c}\text { Escherichia } \\
\text { coli }\end{array}$ & $\begin{array}{c}\text { Salmonelles } \\
\text { Spp }\end{array}$ \\
\hline Altitude (m) & -0.03 & -0.083 & 0.03 & 0.159 \\
\hline Piezometric level (m) & 0.337 & 0.256 & 0.35 & -0.05 \\
\hline Water layer $(\mathrm{m})$ & -0.306 & -0.322 & -0.188 & $-0.589\left(^{* *}\right)$ \\
\hline Well depth $(\mathrm{m})$ & 0.093 & 0.057 & 0.168 & -0.302 \\
\hline Well diameter $(\mathrm{m})$ & -0.082 & -0.129 & -0.117 & -0.034 \\
\hline Curb height $(\mathrm{m})$ & -0.17 & -0.074 & -0.017 & -0.063 \\
\hline Diameters with latrine $(\mathrm{m})$ & -0.103 & -0.145 & -0.31 & -0.265 \\
\hline Temperature $\left({ }^{\circ} \mathrm{C}\right)$ & 0.131 & 0.19 & 0.311 & 0.129 \\
\hline $\mathrm{pH}(\mathrm{CU})$ & $0.638(* *)$ & $0.656\left(^{* *}\right)$ & 0.29 & $0.651\left(^{* *}\right)$ \\
\hline Suspended Solids (mg/L) & 0.068 & 0.001 & 0.006 & 0.247 \\
\hline Turbidity (FTU) & $0.513\left(^{* *}\right)$ & 0.365 & $0.482(* *)$ & 0.361 \\
\hline Electrical Conductivity $(\mu \mathrm{S} / \mathrm{Cm})$ & -0.066 & -0.017 & 0.05 & -0.207 \\
\hline Total hardness $\left(\mathrm{mg} / \mathrm{L} \mathrm{CaCO}_{4}\right)$ & -0.094 & -0.032 & -0.059 & -0.204 \\
\hline Dissolved oxygen (\%) & $0.475\left(^{*}\right)$ & $0.433\left(^{*}\right)$ & $0.379\left(^{*}\right)$ & $0.588\left(^{* *}\right)$ \\
\hline $\mathrm{DBO}_{5}\left(\mathrm{mg} / \mathrm{L} \mathrm{O}_{2}\right)$ & $-0.446\left(^{*}\right)$ & $-0.445\left(^{*}\right)$ & -0.336 & $-0.391\left(^{*}\right)$ \\
\hline $\mathrm{COD}\left(\mathrm{mg} / \mathrm{L} \mathrm{O}_{2}\right)$ & -0.18 & -0.139 & 0.072 & -0.17 \\
\hline Organic matter $\left(\mathrm{mg} / \mathrm{L} \mathrm{O}_{2}\right)$ & 0.203 & 0.204 & 0.28 & 0.091 \\
\hline
\end{tabular}


Spearman correlation showed that the bacterial density were positively and significantly correlated to the following variables: $\mathrm{pH}(\mathrm{r}=0.638$; $\mathrm{p}>0.05)$ for $\mathrm{CT}$; $\mathrm{pH}(\mathrm{r}=0.656$; $\mathrm{p}>0.05)$ for $\mathrm{CF}$; $\mathrm{pH}(\mathrm{r}=0.651 ; \mathrm{p}>0.05)$ for Sal. Turb ( $\mathrm{r}=0.513$; $\mathrm{p}>0.05)$ for CT; Turb ( $\mathrm{r}=0.482$; $\mathrm{p}>0.05)$ for EC; Oxy $(\mathrm{r}=0.588$; $\mathrm{p}>0.05)$ and negatively and significantly EC ( $\mathrm{r}=-0.589$; $p>0.05$ ) for Sal, BOD5 ( $r=-0.445 ; p>0.05$ ) for CF. These results reveal that the bacterial density increases when the level of mineralization of water increases. The density increases with increasing TSS, turbidity and total water hardness. Statistically significant positive correlations were established between bacterial abundances and TSS in the well water samples by [23]. The organic parameter data do confirm this contamination as the ratios of COD/BOD 5 values are nonzero in the majority of well waters. According to Sherer [24], resuspension of particulate matter is generally accompanied by increased bacterial abundance in the medium. The strong negative correlations (Table 6) recorded between the bacteriological variables would reflect competition between the microorganisms. The strong positive correlations (Table 6) would reflect a metabolic symbiosis or a release of microorganisms into the environment.

\section{Conclusion}

These results permit to some edifying knowledge has emerged that has led to an understanding of the impact of anthropogenic pollution on the quality of well water consumed by the inhabitants of the two sub-divisions of Moundou city. Similarly, the health risks that this population faces when consuming this water. Overall, the well water analyzed were acidic, highly mineralized, poorly oxygenated and rich in organic matter. The results of the water analyses confirm a massive presence of total and fecal coliforms, Escherichia coli and Salmonella spp. in the water studied. The nature of the germs encountered and their quantity exceeded the standards recommended for drinking water make these waters unsafe for human consumption without treatment. This is undoubtedly a threat for the inhabitants of the sub-divisions of the city of Moundou. Therefore, to avoid the any health risk, this water should not be used by humans for drinking but can be used for other domestic activities. It is recommended that water be treated at the family level by filtration, boiling and the use of hypochlorite before any consumption. The increase of the sewerage network for the evaluation of wastewater. Garbage collection must be implemented.

\section{Compliance with ethical standards}

\section{Acknowledgments}

I would like to thank Mr. TEDEBAYE Rogoum, Mrs. TAMDI Odile and Mr. DINGAMNAEL Valentin for their help with the physicochemical and bacteriological analyses carried out at the Water and Environment Laboratory of the University of N'Djamena and at the General Bacteriology Laboratory of the Institute of Research in Animal Husbandry for Development (IRED) in N'Djamena.

\section{Disclosure of conflict of interest}

The authors declare that there is no conflict of interest regarding the publication of this document.

\section{References}

[1] Hounsounou EO, Agassounon Djikpo Tchibozo M, Kelome NC, Vissin EW, Mensah GA, Agbossou E. (2016). Pollution of water for domestic uses in disadvantaged urban environments in developing countries: Literature review. Int. J. Biol. Chem. Sci., 10(5), 2392-2412.

[2] Zébazé Togouet SH, Tuekam Kayo RP, Boutin C, Nola M, Foto Menbohan S. (2011). Impact of anthropogenic pressure on water and aquatic fauna in wells and springs of Yaoundé (Cameroon, Central Africa). Bulletin de la Société d'Histoire Nature, Toulouse. 147, 27-41.

[3] World Bank (2019). Note on the water and sanitation sector in Chad, 55.

[4] Mics Chad (2015). Multiple indicator cluster survey. Republic of Chad, Ministry of Planning, Economy and International Cooperation; UNICEF-EDS-MICS, 29.

[5] WHO/UNICEF (World Health Organization/United Nations Children's Fund) (2008). An Overview of the Drinking Water Situation in Africa. 11th African Union Summit of Heads of State and Government on Achieving the Millennium Development Goals on Water and Sanitation, 13.

[6] WHO/UNICEF (2019). Joint Monitoring Program - Progress on Drinking Water, Sanitation and Hygiene, 140. 
[7] Nola M, Njiné T, Djuikom E, Sikati FV. (2002). Faecal coliforms and faecal streptococci community in the underground water in an equatorial area in Cameroon (Central Africa): the importance of some environmental chemical factors. Water Res., 36, 3289-3297.

[8] Maoudombaye T, Bodering A, Mahamat SAM, Ndoutamia G, Ngakou A. (2019). Serotyping Isolated Strains of Salmonella for Consomption in the Eastern Logone Province in Chad, 7(1), 43-48.

[9] Ngoay-Kossy JC, Zébazé Togouet SH, Bolevane Ouantinam SF, Makatia Wango SP, Tchuem Tchuenté LA. (2018). Influence Steeping of the Cassava Tubers on the Physico-Chemical Quality of Water and the Population of the Benthic Macroinvertebrates of River Pala in Central African Republic (CAR). International Journal of Science and Research (IJSR), 7(1), 2077-2088.

[10] Tuekam Kayo RP. (2013). Faunistic biotypology test of groundwater from some localities in the Center and Littoral regions of Cameroon: influence of some abiotic factors. Doctorate / PhD thesis, Faculty of Sciences. University of Yaoundé I, 291.

[11] Nana Nkemegni G, Zébazé Togouet SH, Fomena A, Pountougnigni OF, Piscart C. (2015). Aquatic invertebrate fauna of wells in a tropical mountain climate, western Cameroon. African Journal of Aquatic Science, 40(4), 393401.

[12] Kadjangaba E, Daïra D, Doumnang Mbaigane JC, Ndoutamia Guelmbaye A, Mahmout Y. (2018). Impact of Hydrochemical Processes on the Quality of Groundwater in the City of N'Djaména-Chad. European Scientific Journal, 14(18), 162.

[13] Maoudombaye T, Ndoutamia G, Ngakou A. (2016). Assessment of the Bacteriological Quality of Water from Wells, Boreholes and Rivers Consumed in the Doba Petroleum Basin in Chad. Int J Recent Sci Res., 7(6), 12236-12243.

[14] Bodering A, Ndoutamia G, Ngandolo BN, Mopate LY, Ngakou A. (2018). Characteristics of poultry farms and evaluation of their level of contamination by Salmonella sp. and Escherichia coli in the towns of N'Djamena and Doba in Chad. Rev. Sci. Tech. Off. Int. Epiz., 37 (3)

[15] Ngaram N, Maoudombaye T, Tarkodjiel M. (2021). Evaluation of Heavy Metals in Drinking Water Resources in the Department of Nyan, Province of Logone Oriental in Chad. American Journal of Applied Chemistry, 9(1), 1320.

[16] MATUH (2008). Environmental and Social Impact Studies - PADUR-Ville de Moundou Subprojects, 91.

[17] Hounsinou P, Mama D, Dovonou F, Alasane A. (2015). Seasonal evolution of the microbiological quality of the natural waters in the township of Abomey-Calavi (South Benin). British Journal of Earth Sciences Research, 3(1), 30-41.

[18] Rodier J, Legube B, Merlet N and Brunet R. (2009). Water's analysis. 9th edition. Dunod, Paris, 1600.

[19] APHA (American Public Health Association). (1998). Standard Methods for Examination of Water and Wastewater. 5th edition, American Public Health Association, Washington, DC. 11-50.

[20] Holt JG, Krieg NR, Sneath P, Staley JT, Williams ST. (2000). Bergey's Manual of Determinative Bacteriology. Lippincott Williams and Wilkins, Philadelphia, 787.

[21] WHO (1971). European drinking water standards; 2nd edition

[22] WHO (2011). Guidelines for drinking water quality. Fourth edition. World Health Organization publication. Geneva, Switzerland, 564.

[23] Moussa D, Njiné T, Nola M, Zébazé Togouet SH, Nougang ME, Djah M. (2010). Changes in bacterial abundances of underground water in response to long time of storage at home in Yaoundé (Cameroon), European Journal of Water Quality, 41, 131-143.

[24] Sherer BM, Miner JR, Moore JA, Buckhouse JC. (1992). Indicator bacterial survival in stream sediments. Int. J. Environ. Qual., 21, 291-295.

[25] Weather-climate Moundou Annual average climatic values (2019-2020). tutiempo.net, (Accessed 07/4/2021)

[26] Tchadanaye NM. (2000). Water issues and water quality in Chad. Final report of the results of analyzes of the quality of drinking water, 25. 
[27] Massang T, Noumi GB, Tchadanaye NM, Dikdim Dangwang JM. (2015). Heavy Metals Pollution Level in Water, Fish and Sediments from the Logone River with in Moundou City (Chad). International Journal of Environmental Monitoring and Analysis, 3(5), 275-281.

[28] Nola M, Njiné T, Boutin C. (1998). Variability of groundwater quality in some stations of Yaoundé (Cameroon). Mémoires de Biospéologie, 25, 183-191.

[29] Belghiti ML, Chahlaoui A, Bengoumi D, El Moustaine R. (2013). Study of the physicochemical and bacteriological quality of groundwater in the Plio Quaternary aquifer in the Meknes region (Morocco). Larhyss Journal, 14, 2136.

[30] Dieng NM, Orban P, Otten J, Stumpp C, Faye S, Dassargues A. (2017). Temporal Changes in Groundwater Quality of the Saloum Coastal Aquifer". Journal of Hydrology: Regional Studies, 9, 163-82.

[31] Dionkas J. (2015). Hydrobiological study of the water quality of some wells and boreholes in the city of N'Djaména. Master's thesis, Faculty of Sciences, University of Yaoundé I, 51.

[32] Jourdan B, Piantone P, Lerouge C, Guyonnet D. (2005). Metal attenuation downstream of waste storage sites ((Bibliographic synthesis), 110.

[33] Er-Raioui H, Bouzid S, Khannous S, Zouag MA. (2011). Groundwater contamination by leachate from public landfills: Case of R'Mel groundwater (Larache Province - North-West Morocco). Int. J. Biol. Chem. Sci., 5(3), 11181134.

[34] Moussa D, Nola M, Gake B, Ebang Menye D, Njine T. (2011). Faecal Contamination of Well Water in Garoua (Cameroon): Importance of Household Storage and Sanitary Hygiene, Int. J. Res. Chem. Environ., 1: 97-103.

[35] Djuikom E, Temgoua E, Jugnia L, Nola M, Baane M. (2009). Bacteriological pollution of water wells used by populations in the Douala Urban Community, Cameroon. Int. J. Biol. Chem. Sci., 3(5), 967-978.

[36] Mbawala AA, Ngassoum MB. (2010). Evaluation of the physicochemical and microbial pollution of well water in Dang-Ngaoundéré (Cameroon). Int. J. Biol. Chem. Sci., 4(6), 1962-1975.

[37] Nougang ME, Moïse N, Djuikom E, Noah OV, Moungang ELM, Bessa HA. (2011). Abundance of Faecal Coliforms and Pathogenic E. Coli Strains in Groundwater in the Coastal Zone of Cameroon (Central Africa), and Relationships with Some Abiotic Parameters. Current Research Journal of Biological Sciences, 3(6), 622-632.

[38] Benodji B. (2012). Physico-chemical and bacteriological characterization of waters in the Boutalbagara watershed in N'Djamena (Chad). Master's thesis, Faculty of Science, University of Yaoundé I, 85.

[39] Nang-yana N. (2013). Comparative study of borehole water quality in the city of N'Djamena (Chad): Case of the 8th sub-division. Dissertation of Design Engineer, Sahel Institute, University of Maroua, 80.

[40] Bricha S, Ounine K, Oulkheir S, EL Haloui N, Attarassi B. (2007). Study of the physicochemical and bacteriological quality of the M'nasra water table (Morocco). Revue Afrique Science, 3(3), 391-404.

[41] Mpakam HG, Kouam Kenmogne GR, Tamo Tatietse T, Maire E, Boeglin JL, Ekodeck GE, Dupre B. (2009). Study of the factors of pollution of water resources in urban areas: case of Bafoussam (West Cameroon). Proceedings of the international colloquium on the theme "climate change and environmental assessment", Niamey (Niger) from 26 to 29 May 27.

[42] Degbey C, Makoutode M, Agueh V, Dramaix M, De Brouwer C. (2011). Francophone study and research notebooks / Health - Factors associated with well water quality and prevalence of waterborne diseases in the commune of Abomey-Calavi (Benin), 21(1).

[43] Yapo OB, Mambo V, Seka A, Ohou MJA, Konan F, Gouzile V, Tidou AS, Kouame KV, Houenou P. (2010). Evaluation of domestic well water quality in poor neighborhoods of four communes of Abidjan (Côte d'Ivoire): Koumassi, Marcory, Port-Bouet and Treichville. Int. J. Biol. Chem. Sci., 4(2), 289-307.

[44] Boubakar HA. (2010). Surface and deep aquifers and urban pollution in Africa: Case of the urban community of Niamey (NIGER), Thesis of the Univ, Abdou Moumouni of Niamey (Niger), 198.

[45] Benajiba MH, Saoud Y, Lamribah A, Ahrikat M, Amajoud N, Ouled-Zian O. (2013). Evaluation of the microbial quality of Martil groundwater in Morocco. Revue des Sciences de l'Eau / Journal of Water Science, 26(3), 223233. 
[46] Bahir M, Mennani A, Jalal M, Fakir Y. (2002). Impact of drought on the water potential of the water table supplying drinking water to the city of Essaouira (Mogador, Morocco). Methodological notes. Science and Planetary Change / Drought, 13-19.

[47] Lalanne F. (2012). Study of water quality along the supply chain at consumer level in 10 villages of the Province of Ganzourgou, (Central Plateau region, Burkina Faso), 71.

[48] Health and Welfare Canada (1978). Guidelines for Canadian Drinking Water. Quality supporting documents. Supply and Services Canada, Hull., 1982.

[49] Elegbede B, Edorh AP, Josse RG, Koumolou L, AïssI KA, Zannou F, Montcho S, Aklikokou K. (2011). Comparative Physico-chemical Characterization of Modern Wells and Boreholes Water in the Cotton Zone of Kérou. J. Rech. Sci. Univ. Lomé (Togo), 13(2), 35-41. 